\title{
THE CHALLENGE OF TRANSFORMING UKRAINIAN ARMED FORCES: HOW SCIENCE SUPPORTS ARMED FORCES' DEVELOPMENT
}

\section{Leonid POLYAKOV}

\begin{abstract}
The First Deputy Minister of Defence of Ukraine examines the challenges of transformation at three levels - conceptual, planning/programming, and implementation of force development programmes - and the main challenges that require scientific support from research organisations in the Ukrainian defence establishment.
\end{abstract}

Keywords: Decision support, scientific organizations, defence planning, budgeting.

For Ukraine, the fundamental achievement in the area of military developments was the creation of the Armed Forces of Ukraine. However, the challenges related to the future development of the Armed Forces require persistent efforts from the defence management agencies. The list of problems includes:

- Ukraine's strategic choice;

- Further development of the security strategy, definition of future roles and models of the armed forces;

- Identifying and implementing key advances in the art of war;

- Decision on the programmes for development of the services and other military formations;

- Transition to new principles of unit training;

- Equipping the Armed Forces with new weapon systems and ammunition;

- Transition from a centralised resource management system to an effective logistics system of the Armed Forces.

As you can see, the problems of the Armed Forces are at different levels and require managerial decisions at different levels. Thus, the main task of military science in the 
support of the Armed Forces' development is to explain the nature of the problem and, based on that information, to search for rational and adequate solutions.

Based on my own experience, in the discussion of the role of science in the development of the Armed Forces we can identify three main areas where scientific analysis could support managerial decisions.

First, at the conceptual and strategic level scientists may contribute to the development of national security concept and strategy through analysis of threats, support to the development of a strategy to provide military security, etc. We consider this as the most complex element. Errors at this level may entail catastrophic effects. Solving these problems requires joint efforts of highly intellectual state leaders, leaders of the Ministry of Defence of Ukraine, and research and analysis organizations. As far as Ukraine is concerned, the difficulties in solving these problems relate primarily to the geo-political place of Ukraine, the level of economic development, the availability of resources, and in particular the lack of diversification of energy sources. These factors have a strong impact on particular decisions we make.

In dealing with these problems the Ministry of Defence relies on:

- The Centre for Military-Strategic Research at the National Defence Academy;

- The Central Scientific Research Institute of the Armed Forces;

- The intellectual capacity of the officers and mid-level officials serving in the Ministry of Defence and the General Staff.

In the past, the joint efforts of the Ministry of Defence, the General Staff and the scientific institutions made it possible to determine the main directions in the development of the Armed Forces and to develop the respective legislative foundation. As of today, the main challenges in the military sphere and the guidance on providing military security of the state are reflected in the Military Doctrine and the draft Military Strategy (final approval of the Strategy is pending).

Indeed, at this strategic level, scientific studies supported the elaboration of the main theoretical statements on the evolving art of war, strategy, and operational art, as well as the development of the main forms in using the Joint Rapid Reaction Forces. Results of these studies were reflected in the Foundation for Preparing and Using the Armed Forces of Ukraine, the Strategic Concept and the Strategic Plan, 2006-2011. In the preparation of these documents we adhered to new principles of strategic planning and employment of the Armed Forces.

At the second level, our main task was to design a set of main and target programmes for the development of the Armed Forces. At this level, scientific organisations were 
instrumental in the process of force transformation, supporting the design of programmes for provision of command and control, personnel, education, material support and supplies, unit training, and infrastructure development. Of particular importance were contributions to the decision-making process on the implementation of these programmes, including work on the associated system of criteria and assessment of effectiveness.

This is the level of identification, systematisation and definition of the structural needs of human resources, weapon systems and military equipment, materiel and military infrastructure. At this level we resolve issues of rational use of limited resources through implementation of the programme-based goal-oriented method, which enabled us to lay the foundation for sound defence planning and force development.

The following scientific and research organisations provide contribution at this level:

- The Joint Scientific and Research Institute of the Armed Forces;

- The Scientific Centre for Combat Employment of Land Forces;

- The State Scientific and Research Aviation Institute;

- The Naval Research Centre;

- The Human Factors Research Institute;

- Scientific and Research Institute of Military Medicine;

- Scientific and Methodological Centre of Military Education.

The main research efforts were focused on analysis and developing proposals related to the elaboration and the implementation of the State Programme for the Development of the Armed Forces, 2006-2011, as well as towards the enhancement of the systems for budget and defence planning.

Special attention was placed on the rationale for improving the existing command and control system. Researchers contributed to the introduction of modern approaches to operations and the drafting of new Operations Manual of the Armed Forces. Research results were used as a basis in defining the structure, functions, and tasks of a new command and control organisation - the Joint Operations Command of the Armed Forces. Supporting studies allowed us to enhance the capacity for evaluation of combat and mobilisation readiness, to program the development of capabilities for emergency medical support and medical evacuation, etc.

The dynamics of international defence cooperation increased dramatically, especially as it concerns the implementation of the NATO-Ukraine Annual Target Plan in the framework of the NATO-Ukraine Action Plan. At this second level the cooperation between scientists of Ukraine and NATO increased significantly. 
Third, at the level which I call "applied, material," our main tasks are to define the requirements towards the future capabilities of military units, weapon systems and military equipment, organisational structures, scientific support, etc., and the ways to meet these requirements. The challenge here is in the practical implementation under resource constraints. Of particular importance in that regard is the development of methods for prioritisation, the increase of efficiency in using limited budget funds, the enhancement of the system for evaluation and control, etc. Thus, the real challenge at this level is not the identification of requirements, but the most rational use of budgets to meet specific requirements.

Scientists provide support at this level through identification of ways for developing armaments and military equipment, approaches to their modernisation, extension of life-cycle, and disposal, efficient maintenance of arsenals, bases and storage depots for missiles and ammunition. Towards that purpose we introduced an automated information and analytical system for monitoring bases, storages, arsenals, and other hazardous installations.

The following scientific and research organizations provide contribution at this level:

- The Central Scientific and Research Institute of the Armed Forces for Armaments and Military Equipment;

- The State Aviation Scientific and Testing Centre;

- The Scientific Centre for Artillery at the Military Artillery Institute;

- The Scientific Centre for Communications and Information;

- The Scientific Centre for Metrology and Military Standards;

- The Scientific and Research Centre of the Armed Forces for Oceanographic Studies.

As we are well aware, the implementation of the programme-based, goal-oriented method into practice has the potential to increase the efficiency in the use of defence resources. We see the current lack of effectiveness and efficiency in the allocation of defence resources as the main problem in the further development of the Armed Forces of Ukraine. Resolving this problem is the main immediate task for our scientists. And here I would like to express my warmest gratitude to Dr. Todor Tagarev for his persistent assistance to the Ministry of Defence of Ukraine for the creation of an effective system for defence planning and harmonising the routine activities of the Armed Forces with the process of planning and executing the state budget. ${ }^{1}$

In conclusion, I would like to express my conviction that this conference will facilitate the systematisation of knowledge and experience in using scientific support in managing the transformation of the Armed Forces of our countries and will greatly assist decision makers dealing with the immense challenges of transformation. 


\section{Notes:}

1 See for example his article "Introduction to Program-Based Defense Resource Management," Connections: The Quarterly Journal 5, no. 1 (Spring-Summer 2006): 55-69, also translated in Ukrainian and published in Nauka i Oborona, no. 3 (2006).

LEONID POLYAKOV is First Deputy Minister of Defence of Ukraine since February 2005. He is graduate of the Kyiv Radio and Electronics College (1979), Kyiv Combined Arms Command School (1983), Frunze Military Academy (1993), the US Army War College (1995), and the George C. Marshall Center for European Security Senior Executive Course (2001). He is veteran of the Afghan campaign (1985-1987), decorated with the order "For Serving the Country in the Armed Forces of the USSR" grade III, merit badge of the Ministry of Defence of Ukraine "Valour and Honour" and medals. In 1999 he retired with the rank of Colonel and joined the "Razumkov" Ukrainian Centre for Economic and Political Studies as Director for Defence Programs. From February 2000 to February 2005, Leonid Polyakov was an invited adviser to the National Security and Defence Committee of the Verkhovna Rada of Ukraine. As NATO Fellow, 1999-2001, Mr. Polyakov worked on The Russian Factor in Ukraine's Relations with NATO: Possible Outcomes and Policy Implications for Ukraine and NATO. His numerous publications touch the broad range of Ukrainian and regional security issues, and include Ukrainian-NATO Relations and New Prospects for Peacekeeping (United Kingdom: The Royal Institute of International Affairs, 2003); Ukraine's Security between Russia and the West [Die Siecherheitspolitic der Ukraine zwischen Russland und dem Westen], Austria: Mittler, Jahrbuch fur internationale Sicherheitspolitic 2002; "Military Reforms in Russia" in Toward an Understanding of Russia. New European Perspectives (New York: Council on Foreign Relations, 2002); and "American Defense Transformation: A View from Ukraine" in Transforming Defense (Carlisle, PA: Strategic Studies Institute, U.S. Army War College, December 2001). 